\title{
Mercury Speciation Comparison: BrooksApplied Laboratories and Eurofins Frontier Global Sciences
}

\section{J. Bannochie}

W. R. Wilmarth

December 2016

SRNL-STI-2016-00622, Revision 0 


\section{DISCLAIMER}

This work was prepared under an agreement with and funded by the U.S. Government. Neither the U.S. Government or its employees, nor any of its contractors, subcontractors or their employees, makes any express or implied:

1. warranty or assumes any legal liability for the accuracy, completeness, or for the use or results of such use of any information, product, or process disclosed; or

2. representation that such use or results of such use would not infringe privately owned rights; or

3. endorsement or recommendation of any specifically identified commercial product, process, or service.

Any views and opinions of authors expressed in this work do not necessarily state or reflect those of the United States Government, or its contractors, or subcontractors.

\section{Printed in the United States of America \\ Prepared for U.S. Department of Energy}


Keywords: Mercury, Speciation, Tank Samples, Tank Farm, DWPF

Retention: Permanent

\section{Mercury Speciation Comparison: Brooks Applied Laboratories and Eurofins Frontier Global Sciences}

C. J. Bannochie

W. R. Wilmarth

December 2016 


\section{REVIEWS AND APPROVALS}

\section{AUTHORS:}

C. J. Bannochie, Process Technology Programs

Date

W. R. Wilmarth, E\&CPT Research Programs

Date

TECHNICAL REVIEW:

S. H. Reboul, Advanced Characterization and Processing, Reviewed per E7 2.60

Date

APPROVAL:

F. M. Pennebaker, Manager, Process Technology Programs

Date

D. E. Dooley, Director, E\&CPT Research Programs

Date

R. E. Edwards, Jr., SRR Engineering

Date 


\section{PREFACE OR ACKNOWLEDGEMENTS}

The authors wish to thank Dr. Michelle Briscoe, Ms. Annie Carter, and Dr. Hakan Gurleyuk at BrooksApplied Laboratories, as well as Dr. Patrick Garcia-Strickland and Mr. Robert Brunette at Eurofins Frontier Global Sciences for technical discussion concerning the samples that are the subject of this report. We also recognize the efforts of Ms. Phyllis Workman and Ms. Dee Wheeler for SRNL Shielded Cells work; Dr. Charles Crawford for technical reviews; Ms. Holly Hall, Mr. Daniel Jones, and Ms. Betty Mealer for laboratory sample preparations; Ms. Victoria Lampkin our Hazardous Material Transportation Representative; and Ms. Sharon Crawford and Ms. Karen Palmer for packaging and shipment services.

The authors thank Savannah River Remediation (SRR), specifically Mr. Hasmukh Shah, Dr. Vijay Jain, and Mr. Richard Edwards for tank sampling efforts and funding to support for this work. 
SRNL-STI-2016-0622

Revision 0

\section{EXECUTIVE SUMMARY}

The Savannah River National Laboratory (SRNL) was tasked with preparing and shipping samples for Hg speciation by Eurofins Frontier Global Sciences (FGS), Inc. in Bothell, WA on behalf of the Savannah River Remediation (SRR) Mercury Program Team. To date, twenty-three shipments have been made to Eurofins FGS. These samples were analyzed for seven species including: total mercury, dissolved mercury, inorganic mercury ((Hg(I) and $\mathrm{Hg}(\mathrm{II}))$, elemental mercury, methylmercury, ethylmercury, and dimethylmercury, with an eighth species, particulate mercury, calculated from the difference between total and dissolved mercury after subtracting the elemental mercury. The species fraction of total mercury measured has ranged broadly from a low of $32 \%$ to a high of $146 \%$, though the vast majority of samples have been $<100 \%$. This can be expected since one is summing multiple values that each have at least a \pm $20 \%$ measurement uncertainty.

Two liquid waste tanks particularly important to understanding the distribution of mercury species in the Savannah River Site (SRS) Tank Farm were selected for a round robin analysis by Eurofins FGS and BrooksApplied Laboratories (BAL). Eurofins FGS is a subcontractor to SRR, and Subcontract No. 248248 was placed between Savannah River Nuclear Solutions (SRNS) and BAL in order to provide a check on the data being received from Eurofins over the past 18 months. The two tanks selected for comparison were the DWPF Recycle Receipt Tank (Tank 22) and the 2H Evaporator Drop Tank (Tank 38). Final sample dilutions for both labs were prepared and shipped to each of the laboratories in Bothell, WA.

The analyses conducted by BAL on the Tank 22 and 38 samples and their agreement with those obtained from Eurofins FGS for total mercury, dissolved mercury, methylmercury, ethylmercury, and dimethylmercury provide a strong degree of confidence in these species measurements for samples submitted since March 2015 to Eurofins FGS.

BrooksApplied Laboratories use of ion pairing chromatography cold vapor inductively coupled mass spectrometry (IP-CV-ICP-MS) to determine inorganic mercury led to a significantly greater inorganic mercury fraction for both Tank 22 (21\% increase) and Tank 38 (40\% increase) over those values determined by Eurofins FGS. Staff at BAL also reported significantly more elemental Hg in both Tank $22(3 x)$ and Tank $38(>4 x)$ than reported by Eurofins FGS. Combining these two factors improved their sum of species fractions to $105 \%$ and $92 \%$ for Tank 22 and 38, respectively. Other than its contribution of an inorganic mercury value, the IP-CV-ICP-MS method did not have detection limits sensitive enough for the other mercury species to exceed those determinations by cold vapor atomic fluorescence spectroscopy (CV-AFS) methods.

This work leads to one recommendation for Eurofins FGS, that they attempt to close the mass balance on their analyses prior to reporting results on future SRS tank and process samples, with particular attention to elemental and inorganic mercury measurements. SRR should evaluate their elemental Hg limits for tanks and process vessels in light of the BAL data since the results reported are considerably higher than those reported by Eurofins.

The second recommendation involves future work by BAL on Tank 39 samples. Originally, there was no expectation for organomercury in this canyon waste receipt tank, but previous Eurofins FGS results ${ }^{19}$ indicated between $6-9 \%$ of the total mercury was methylmercury. However, the sum of species fractions was very low, between 47-51\% for the surface and depth samples. Questions that could be addressed by BAL include, "Are there other organomercury species present in this tank and/or would a reanalysis of this tank lead to a better overall mass balance and improved understanding of the chemistry that may be contributing to organomercury species formation?” 


\section{TABLE OF CONTENTS}

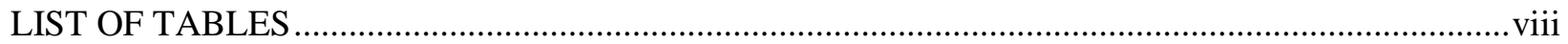

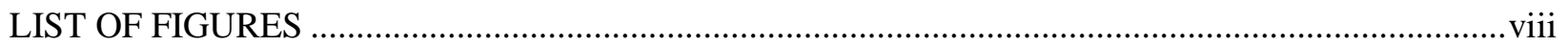

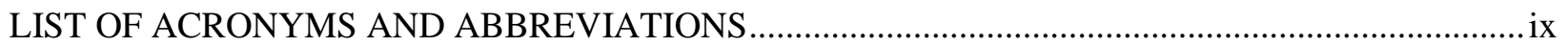

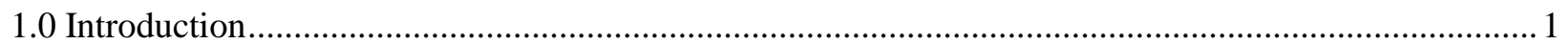

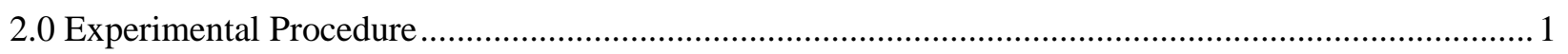

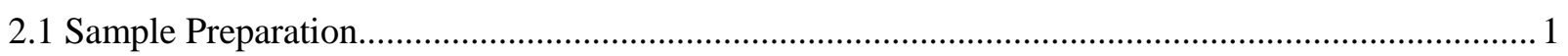

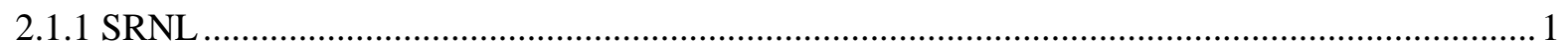

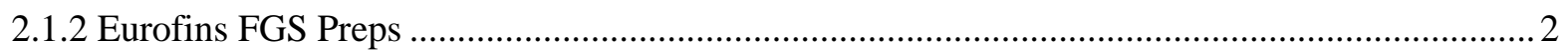

2.1.3 BrooksApplied Laboratories Preps ........................................................................................ 2

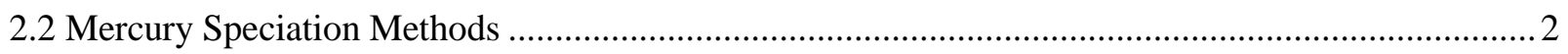

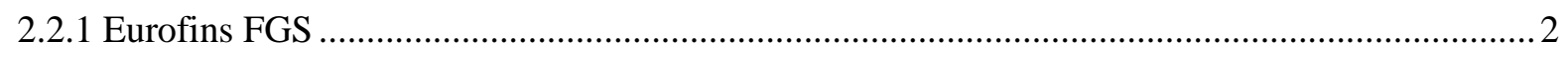

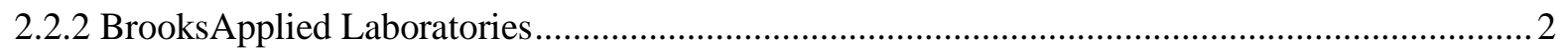

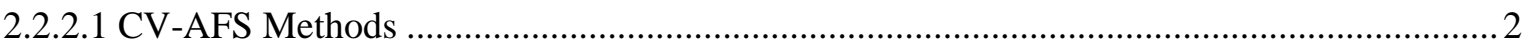

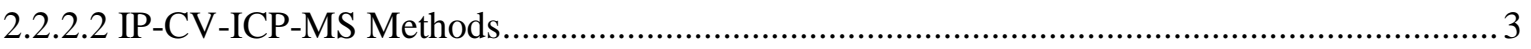

2.3 BAL Dimethylmercury Holding Time Study ................................................................................ 3

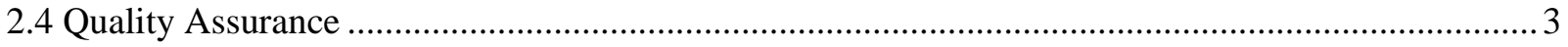

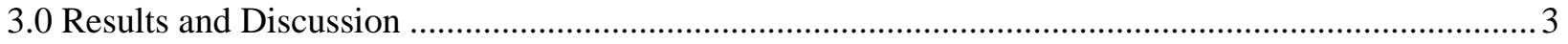

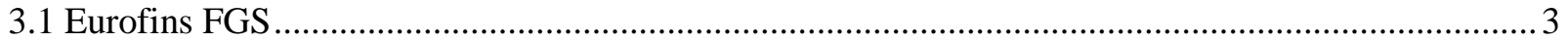

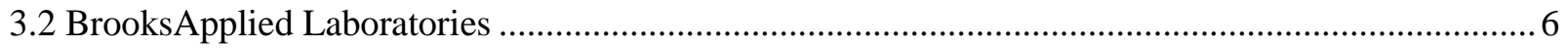

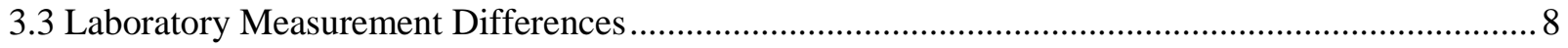

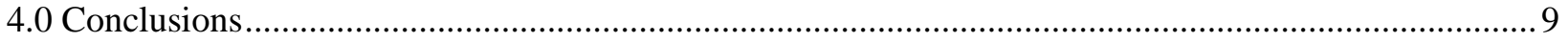

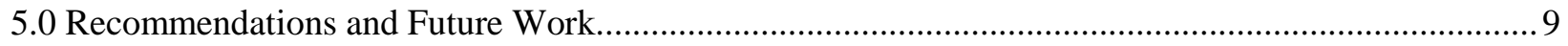

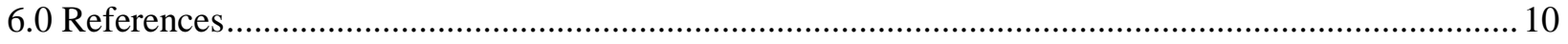




\section{LIST OF TABLES}

Table 3-1 Eurofins Average Concentrations of various Hg species for Tank Samples expressed as mg $\mathrm{Hg} / \mathrm{L}$ (ppm) [\%RSD] (No. of Replicates) ..................................................................................... 5

Table 3-2 BrooksApplied Average Concentrations of various Hg species for Tank Samples expressed as mg Hg/L (ppm) [\%RSD] (No. of Replicates) ……............................................................................ 5

Table 3-3 Percent of Methylmercury as a Fraction of Total Mercury ….................................................... 7

\section{LIST OF FIGURES}

Figure 3-1 Loss of dimethylmercury over time from three Teflon ${ }^{\circledR}$ bottles. ........................................... 6

Figure 3-2 Example of mercury speciation by the BAL IP-CV-ICP-MS method. Peak labeled as Hg(II) is

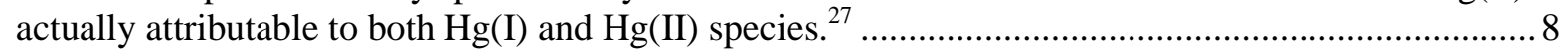




\section{LIST OF ACRONYMS AND ABBREVIATIONS}

(Excludes element symbols from the Periodic Table of the Elements)

$\begin{array}{ll}\text { AD } & \text { Analytical Development } \\ \text { AFS } & \text { Atomic Fluorescence Spectroscopy } \\ \text { BAL } & \text { BrooksApplied Laboratories } \\ \text { CV } & \text { Cold Vapor } \\ \text { DMeHg } & \text { Dimethylmercury (BAL usage only) } \\ \text { FGS } & \text { Frontier Global Sciences } \\ \text { GC } & \text { Gas Chromatography } \\ \text { HMTR } & \text { Hazardous Material Transportation Representative } \\ \text { HTF } & \text { H-Tank Farm } \\ \text { ICP-MS } & \text { Inductively Coupled Plasma - Mass Spectrometry } \\ \text { IP } & \text { Ion Pairing Chromatography } \\ \text { L } & \text { Liter } \\ \text { Hg } & \text { Microgram } \\ \text { MDL } & \text { Minimum Detection Limit } \\ \text { ng } & \text { Nanogram } \\ \text { SOP } & \text { Standard Operating Procedure } \\ \text { SRNL } & \text { Savannah River National Laboratory } \\ \text { SRNS } & \text { Savannah River Nuclear Solutions } \\ \text { SRR } & \text { Savannah River Remediation } \\ \text { SRS } & \text { Savannah River Site }\end{array}$




\subsection{Introduction}

The Savannah River National Laboratory (SRNL) was tasked with preparing and shipping samples for Hg speciation by Eurofins Frontier Global Sciences (FGS), Inc. in Bothell, WA on behalf of the Savannah River Remediation (SRR) Mercury Task Team. ${ }^{1,2}$ To date, twenty-three shipments have been made to Eurofins FGS. ${ }^{3,4,5,6,7,8,9,10,11,12,13,14,15,16,17,18,19,20,21,22}$ These samples, typically three per shipment, were analyzed for seven species including: total mercury, dissolved mercury, inorganic mercury ((Hg(I) and Hg(II)), elemental mercury, methylmercury, ethylmercury, and dimethylmercury, with an eighth species, particulate mercury calculated from the difference between total and dissolved mercury after subtracting the elemental mercury. The species fraction ${ }^{i}$ of total mercury measured has ranged broadly from a low of $32 \%$ to a high of $146 \%$, though the vast majority of samples have been $<100 \%$. This can be expected since one is summing multiple values that each have at least a $\pm 20 \%$ measurement uncertainty.

Two liquid waste tanks particularly important to understanding the distribution of mercury species in the SRS Tank Farm were selected for an informal round robin analysis by Eurofins FGS and BrooksApplied Laboratories (BAL). Eurofins FGS is a subcontractor to SRR, but Subcontract No. 248248 was placed between Savannah River Nuclear Solutions (SRNS) and BAL in order to provide a check on the data being received from Eurofins over the past 18 months. The two tanks selected for comparison were the DWPF Recycle Receipt Tank (Tank 22) and the 3H Evaporator Drop Tank (Tank 38). Final sample dilutions (described later) for both labs were prepared on the same day and shipped the following day by overnight express parcel service to each of the laboratories in Bothell, WA.

\subsection{Experimental Procedure}

\subsection{Sample Preparation}

\subsubsection{SRNL}

Two Tank 38 samples arrived at SRNL on April 7, 2016. The sample designated HTF-38-16-26 was a surface sample and was not sent for mercury speciation. The second sample, designated HTF-38-16-27 or the "depth" sample, was taken at the Tank's jet suction height, 248" from the tank bottom. Approximately $1 \mathrm{~g}$ of the depth sample was withdrawn from the $82 \mathrm{~mL}$ stainless steel sampling vessel immediately upon opening and diluted in the SRNL Shielded Cells to $100.00 \mathrm{~mL}$ with Eurofins deionized water using a volumetric flask. A $30 \mathrm{~mL}$ Teflon ${ }^{\circledR}$ bottle was rinsed twice with the diluted tank sample and filled to leave no head space. The $30 \mathrm{~mL}$ subsample was immediately removed from the cells and transferred to refrigerated storage at $4-5{ }^{\circ} \mathrm{C}$, where it remained until final dilutions for Eurofins and BAL. A second subsample of the diluted tank material was sent to Analytical Development (AD) for radionuclide characterization, specifically, gamma scan, Cs-removed gamma scan, Sr-90, Tc-99, I-129, and $\mathrm{Pu}$ isotopes.

A single Tank 22 sample arrived at SRNL on April 25, 2016. The sample designated HTF-22-16-39 was collected at the Tank's pump suction depth of 62 inches. Approximately $1 \mathrm{~g}$ of the sample was withdrawn from the $82 \mathrm{~mL}$ stainless steel sampling vessel immediately upon opening and diluted with BAL deionized water using a volumetric flask. Subsamples for final dilutions and radionuclide characterization were taken as described above for Tank 38. Both tank samples were taken for supernate and the tanks were not mixed prior to sampling.

\footnotetext{
${ }^{\mathrm{i}}$ The species fraction is calculated by summing the particulate mercury, elemental mercury, inorganic mercury, methylmercury, ethylmercury, and dimethylmercury, and dividing by the total mercury and multiplying by 100 .
} 
After receipt of $\mathrm{AD}$ radionuclide data, final dilution calculations were performed in order to keep the respective shipments below the limits of the Eurofins and BAL Washington State Radioactive Material Licenses. The dilution calculations, recorded in the SRNL E-Notebook system ${ }^{23}$, were peer reviewed prior to submission to the Savannah River Nuclear Solutions (SRNS) Hazardous Material Transportation Representative (HMTR). The Tank 22 sample was diluted by nominally 1:260,000 on a volume basis, while the Tank 38 sample was diluted by nominally 1:300,000 (on a volume basis) before each sample was further prepared by the receiving laboratory.

\subsubsection{Eurofins FGS Preps}

A total of forty-eight, $250 \mathrm{~mL}$ glass bottles were shipped at nominally $4{ }^{\circ} \mathrm{C}$ overnight to Eurofins FGS on July 27, 2016. The samples were received the next day. The shipment included a set of dilutions for a Quarterly Tank 50 WAC sample, the results for which have been reported elsewhere. ${ }^{24}$ Of the results reported in this document, 24 bottles contained $0.100 \mathrm{~mL}$ of radioactive material from cells diluted Tank 22 and 38 subsamples and 8 bottles were blanks made from SRNL derived deionized water. Eight bottles were preserved with $1.2 \mathrm{~mL}$ of concentrated $\mathrm{HCl}$ for methyl- and ethylmercury determination. Eight bottles for dimethylmercury determination were prepared in amber glass. Eight bottles were prepared for total and dissolved mercury, and the final eight bottles were for elemental and inorganic mercury determinations.

\subsubsection{BrooksApplied Laboratories Preps}

A total of forty, $250 \mathrm{~mL}$ glass bottles were shipped at nominally $4{ }^{\circ} \mathrm{C}$ overnight to BAL on July 17, 2016. The samples were received the next day. Of this total, 30 contained $0.100 \mathrm{~mL}$ of radioactive material from cells diluted Tank 22 and 38 subsamples and 10 bottles were blanks made from SRNL derived deionized water. Ten bottles were preserved with $1.0 \mathrm{~mL}$ of degassed, concentrated $\mathrm{HCl}$ for methyl-, ethyl-, and inorganic mercury determination. Ten bottles were preserved with 10\% 2-propanol for dimethylmercury measurement. Thirty bottles were unpreserved with ten of these bottles analyzed for total volatile mercury, ten bottles analyzed for dissolved mercury, and the final ten bottles for total mercury.

\section{2 $\underline{\text { Mercury Speciation Methods }}$}

\subsubsection{Eurofins FGS}

The Eurofins FGS characterization methods for each mercury species have been described elsewhere. ${ }^{25}$ Eurofins reported results in ng $\mathrm{Hg} / \mathrm{L}$ and measured the density of one set of dilutions for each tank sample for use in dilution corrections.

\subsubsection{BrooksApplied Laboratories}

Sample preservation/oxidation took place in the original bottles for total mercury with bromine monochloride $(\mathrm{BrCl})$. The dissolved mercury bottles were filtered through a pre-cleaned 0.45 - $\mu \mathrm{m}$ filter unit and the filtrate returned to the triple-rinsed original container for preservation/oxidation with $\mathrm{BrCl}$. Both analyses were performed in triplicate on reach replicate.

\subsubsection{CV-AFS Methods}

Sample results determined from cold vapor atomic fluorescence spectroscopy (CV-AFS) were method blank corrected per BAL Standard Operating Procedures (SOP) and included the determinations for total and dissolved mercury (EPA 1631), methylmercury (EPA 1630), total volatile mercury, ethylmercury by CV-AFS, dimethylmercury by CV-AFS, and particulate mercury. Sample results from CV-AFS were reported on a ng/L basis and results from ion pairing chromatography cold vapor inductively couple mass spectrometry (IP-CV-ICP-MS) were reported in $\mu \mathrm{g} / \mathrm{L}$. 
Methylmercury determination was made by distillation, with the distillates analyzed by ethylation, Tenax trap collection, gas chromatography (GC) separation, isothermal decomposition, and CV-AFS detection using a Brooks Rand Instruments MERX-M CV-AFS Automated Analyzer.

Ethylmercury determination was also made by distillation, with the distillates analyzed by propylation, Tenax trap collection, GC separation, isothermal decomposition, and CV-AFS detection using a Brooks Rand Instruments MERX-M CV-AFS Automated Analyzer.

Dimethylmercury was determined by cold vapor gas chromatography atomic fluorescence spectroscopy (CV-GC-AFS) due to its high sensitivity and extremely low minimum detection limits (MDL $=0.009$ $\mathrm{ng} / \mathrm{L}$ ). The detection limit is usually impacted by elemental $\mathrm{Hg}$ which elutes very close to that of dimethylmercury with an average retention time difference of 0.13 seconds.

\subsubsection{IP-CV-ICP-MS Methods}

BAL's method for methylmercury by ion pairing chromatography cold vapor inductively coupled mass spectrometry (IP-CV-ICP-MS) was utilized for the simultaneous determination of methylmercury, ethylmercury, phenylmercury, and inorganic mercury. Samples were injected into a C18 column and separated according to their interactions with an unspecified ion-pair reagent and the stationary phase. The eluting mercury species were oxidized in a flow injection system with $\mathrm{BrCl}$ before being converted into elemental mercury using a strong reductant. The inorganic mercury MDL was $0.6 \mathrm{ng} / \mathrm{L}$ and the methylmercury MDL was $1.4 \mathrm{ng} / \mathrm{L}$. The measurement of ethyl- and phenylmercury were qualitative since these species are not fully oxidized and converted to inorganic mercury in the flow injection system. The inorganic mercury value determined from this method was employed in the mass balance calculations for the CV-AFS generated data.

\subsection{BAL Dimethylmercury Holding Time Study}

125 -mL Teflon ${ }^{\circledR}$ bottles were filled to zero-headspace with a solution of $1000 \mathrm{ng} / \mathrm{L}$ dimethylmercury. The bottles were stored at $4{ }^{\circ} \mathrm{C}$ until analysis for dimethylmercury by CV-AFS. In order to minimize the impact from loss of dimethylmercury volatilizing from the samples after subsequent opening/closing events, three bottles were prepared. One bottle was tested on Day 21, that bottle and the second bottle were tested on Day 45, and all three bottles were tested on Day 77.

An aliquot of the sample was also collected on Day 77 and oxidized for total mercury determination.

\subsection{Quality Assurance}

Requirements for performing reviews of technical reports and the extent of review are established in manual E7 2.60. SRNL documents the extent and type of review using the SRNL Technical Report Design Checklist contained in WSRC-IM-2002-00011, Rev. 2.

\subsection{Results and Discussion}

\subsection{Eurofins FGS}

Table 3-1 summarizes the results from Eurofins FGS on the Tank 22 and 38 samples after correcting for SRNL dilutions of the original tank samples. The analysis methodology utilized for this Tank 22 (and 38) sample was significantly different from that employed for the first Tank 22 sample. ${ }^{5}$ This time, elemental mercury was determined on a separate set of replicates from those utilized for the dimethylmercury measurements, thereby eliminating some of the sampling losses and high replicate variability seen previously. Inorganic mercury was measured after purging the samples of elemental mercury (i.e. 
dissolved gaseous mercury), thereby eliminating the double counting of the elemental mercury fraction. The mass balance was good at $81-92 \%$ (excluding detection limit values) for the two samples. 
Table 3-1 Eurofins Average Concentrations of various Hg species for Tank Samples expressed as mg Hg/L (ppm) [\%RSD] (No. of Replicates)

\begin{tabular}{|c|c|c|c|c|c|c|c|c|c|}
\hline Sample & $\begin{array}{l}\text { Total } \\
\text { Hg }\end{array}$ & $\begin{array}{c}\text { Total } \\
\text { Soluble } \\
\text { Hg }\end{array}$ & $\begin{array}{c}\text { Particulate } \\
\text { Hg }\end{array}$ & $\begin{array}{c}\text { Elemental Hg } \\
{[\operatorname{Hg}(0)]}\end{array}$ & $\begin{array}{c}\text { Inorganic Hg } \\
\text { [Hg(I) \& } \\
\text { Hg(II)] }\end{array}$ & $\begin{array}{c}\text { Methyl } \\
\text { Hg }\end{array}$ & $\begin{array}{c}\text { Ethyl } \\
\text { Hg }\end{array}$ & $\begin{array}{c}\text { Dimethyl } \\
\text { Hg }\end{array}$ & $\begin{array}{c}\text { Species } \\
\text { Fraction of } \\
\text { Total Hg }\end{array}$ \\
\hline Method $\rightarrow$ & $\begin{array}{c}\text { CV-AFS } \\
\text { EPA 1631E }\end{array}$ & $\begin{array}{c}\text { CV-AFS } \\
\text { EPA 1631E }\end{array}$ & Calculation & $\begin{array}{c}\text { CV-AFS } \\
\text { EPA } 1631 \text { Mod }\end{array}$ & $\begin{array}{c}\text { CV-AFS } \\
\text { EPA } 1631 \text { Mod }\end{array}$ & $\begin{array}{l}\text { CV-AFS } \\
\text { EPA } 1630\end{array}$ & CV-AFS & $\begin{array}{l}\text { CV-AFS } \\
\text { FGS-070 }\end{array}$ & --- \\
\hline Tank 22 & 105 [1.5] (3) & $97.9[2.9]$ (3) & 3.8 & 3.13 [7.3] (3) & 74.9 [35] (3) & 15.1 [15] (3) & $<1.9$ & $<0.053$ & $92-94 \%$ \\
\hline Tank 38 & 331 [1.8] (3) & 292 [1.3] (3) & 27 & 12.5 [23] (3) & 65.7 [6.1] (3) & 163 [3.1] (3) & $<2.1$ & $0.0459[10]$ (3) & $81-82 \%$ \\
\hline
\end{tabular}

Table 3-2 BrooksApplied Average Concentrations of various Hg species for Tank Samples expressed as mg Hg/L (ppm) [\%RSD] (No. of Replicates)

\begin{tabular}{|c|c|c|c|c|c|c|c|c|c|}
\hline Sample & $\begin{array}{c}\text { Total } \\
\text { Hg }\end{array}$ & $\begin{array}{c}\text { Total } \\
\text { Soluble } \\
\text { Hg }\end{array}$ & $\begin{array}{c}\text { Particulate } \\
\text { Hg* }\end{array}$ & $\begin{array}{c}\text { Total Volatile } \\
\text { Hg } \\
\text { [Hg(0) \& } \\
\text { DMHg] } \ddagger \\
\end{array}$ & $\begin{array}{c}\text { Inorganic Hg } \\
\text { [Hg(I) \& } \\
\text { Hg(II)] }\end{array}$ & $\begin{array}{c}\text { Methyl } \\
\text { Hg }\end{array}$ & $\begin{array}{c}\text { Ethyl } \\
\text { Hg }\end{array}$ & $\begin{array}{c}\text { Dimethyl } \\
\text { Hg }\end{array}$ & $\begin{array}{c}\text { Species } \\
\text { Fraction of } \\
\text { Total Hg }\end{array}$ \\
\hline Method $\rightarrow$ & $\begin{array}{l}\text { CV-AFS } \\
\text { EPA 1631E }\end{array}$ & $\begin{array}{c}\text { CV-AFS } \\
\text { EPA 1631E }\end{array}$ & Calculation & $\begin{array}{c}\text { CV-AFS } \\
\text { EPA } 1631 \text { Mod }\end{array}$ & IP-CV-ICP-MS & $\begin{array}{l}\text { CV-AFS } \\
\text { EPA } 1630\end{array}$ & CV-AFS & CV-AFS & --- \\
\hline Tank 22 & 110 [1.2] (3) & 102 [2.1] (3) & $\sim 0$ & $9.60[4.4](3)$ & 90.4 [1.8] (3) & 15.0 [6.2] (3) & $<0.0011$ & 0.00679 [NA] (1) & $105 \%$ \\
\hline Tank 38 & $329[0.28]$ (3) & 299 [0.93] (3) & $\sim 0$ & 55.5 [4.5] (3) & 93.9 [2.1] (3) & 154 [2.8] (3) & $0.198(1)$ & 0.0388 [30] (3) & $92 \%$ \\
\hline
\end{tabular}

* Total Hg minus the sum of Total Soluble Hg and Total Volatile Hg leads to a negative value, so it is given here as $\sim 0$.

$\ddagger$ Initially BAL believed DMHg may amalgamate with gold on the traps they utilize, but subsequent discussions indicate that they no longer believe this, hence this values should be considered $\operatorname{Hg}(0)$. 


\subsection{BrooksApplied Laboratories}

The Holding Time Study conducted by BAL indicates that the vast majority of dimethylmercury is lost over time from the storage of dimethylmercury containing samples in Teflon ${ }^{\circledR}$ bottles consistent with the advice in EPA Method 1630 Appendix A that recommends a maximum 48 hour hold time prior to analysis and the use of glass bottles with no headspace. ${ }^{26}$ Additionally, BAL recommends the use of chilled reagents and bottles when making final dilutions to minimize volatilization of dimethylmercury. Due to the time required for the radioactive material practices and weighing that surround these final dilutions, the use of chilled reagents and bottles may not be feasible. Figure 3-1 shows the loss of dimethylmercury from aqueous solutions stored in three Teflon ${ }^{\circledR}$ bottles. Bottle \#1 was sampled on Day 21, Day 45 and Day 77, Bottle \#2 was sampled on Days 21 and 45, while Bottle \#3 was sampled on only Day 77. This was done to minimize the impact of loss from dimethylmercury volatilization from the samples after subsequent opening/closing events.

In light of the long lag time and multiple handling steps caused by Tank Farm sampling, transport to SRNL, initial cells dilution, radionuclide analysis, HMTR shipping calculations, final dilution to reduce radionuclide levels, and shipment for analysis, dimethylmercury analyses on previous tank samples should be considered to be biased very low. The 3Q16 and 4Q16 Tank 50 WAC samples have been subsampled into glass vials prior to final dilution for dimethylmercury measurement (Teflon bottles continue to be used for intermediate sample storage for materials destined for methyl- and ethylmercury analysis since these species are known to be highly sorptive, and they can adhere even to Teflon surfaces). Additionally, Tank 50 material does not undergo initial dilution in the Shielded Cells, therefore it undergoes less manipulation prior to analysis, which should reduce the low bias on these samples, though it is unlikely to completely eliminate it. Eurofins FGS has also observed that each subsequent sampling event from a bottle for dimethylmercury leads to a lower measurement value.

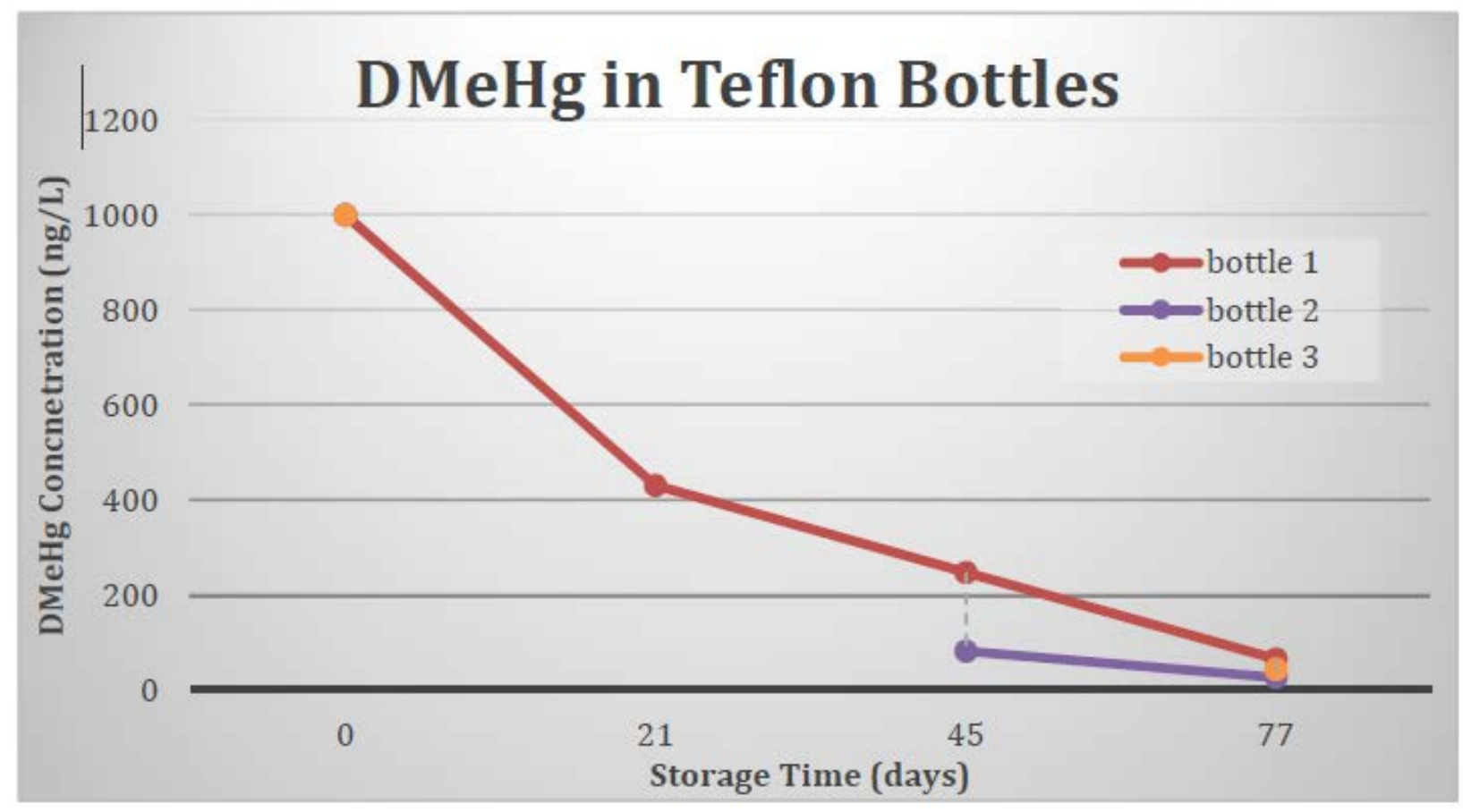

Figure 3-1 Loss of dimethylmercury over time from three Teflon ${ }^{\circledR}$ bottles. ${ }^{27}$ 
While BAL performed a mass balance on their results, their reported results did not take into account the SRNL dilution data for each replicate. The data shown in Table 3-2 summarizes the best data from the BAL study of Tanks 22 and 38 after correcting for SRNL dilutions on the original samples. The densities of the Tank 22 and 38 samples were measured in SRNL, however, the Tank 38 density was determined on the surface sample, which may be less dense then the depth sample. A lower density would bias the final result lower than they may actually be for each species, but since the same density is used to correct both the Eurofins and BAL data, the relative comparison of the data sets between laboratories is not impacted.

Comparing the data sets in Table 3-1 and Table 3-2, there is excellent agreement between the values for total mercury, dissolved mercury, methylmercury, ethylmercury, and dimethylmercury. The place where the two labs differ is elemental mercury (Eurofins) or total volatile mercury (BAL), and inorganic mercury. First, since there is essentially no dimethylmercury in either Tank sample and the fact that BAL utilized a gold amalgam trap which is not sensitive to dimethylmercury, the total volatile mercury measurement from BAL is equivalent to the elemental mercury measurement from Eurofins. However, BAL reported approximately 3 - 4 times the level of elemental mercury (dissolved gaseous mercury) than Eurofins reported. Additionally, the BAL direct measurement of inorganic mercury by IP-CV-ICP-MS is quite different from the operationally defined inorganic mercury measurement made by Eurofins, which is the mercury measured after sparging to remove elemental mercury, followed by reduction of inorganic mercury with $\mathrm{SnCl}_{2}$, purging and trapping the elemental $\mathrm{Hg}$ produced in the reduction onto gold traps, and finally thermally desorbing the trapped mercury into a CV-AFS. The large number of manipulations in the Eurofins method may be biasing the inorganic mercury measurement low.

Interestingly, the ratio of methylmercury to total mercury has changed for both Tank $22^{5}$ and $38^{9}$ from that measured previously during the 2015 shipments. Table 3-3 shows the methylmercury measured in both tanks as a percentage of total mercury. The agreement between the Eurofins and BAL values is excellent. The ratio of methylmercury to total mercury appears to have dropped by almost a factor of two for Tank 22, but increased by about 40\% between the 2015 and 2016 Tank 38 samples.

Table 3-3 Percent of Methylmercury as a Fraction of Total Mercury

\begin{tabular}{|l|c|c|c|}
\hline \multicolumn{1}{|c|}{ Sample } & $\mathbf{2 0 1 5}$ & \multicolumn{2}{c|}{$\mathbf{2 0 1 6}$} \\
\hline & Eurofins & Eurofins & BAL \\
\hline $\begin{array}{l}\text { Tank 22 } \\
\text { Subsurface }\end{array}$ & $26 \%$ & $14 \%$ & $14 \%$ \\
\hline $\begin{array}{l}\text { Tank 38 } \\
\text { Subsurface }\end{array}$ & $34 \%$ & $49 \%$ & $47 \%$ \\
\hline
\end{tabular}

Another observation that can be drawn from both the Eurofins (Table 3-1) and BAL data (Table 3-2) concerns the elemental mercury concentration in the two tank wastes. Both labs describe the elemental mercury they measure as dissolved gaseous mercury, which is consistent with the expected form in the highly dilute solutions they receive for analysis from SRNL. The anticipated solubility of elemental mercury is $0.0608 \mathrm{mg} / \mathrm{L}$ at $0{ }^{\circ} \mathrm{C}{ }^{28} \quad$ However, when the dilution factors of $260-300 \mathrm{~K}$ are applied to the reported results, the concentration of elemental $\mathrm{Hg}$ would imply either a second phase, or a much greater solubility for elemental mercury in the highly alkaline salt waste. The Eurofins reported elemental mercury data for Tank 22 exceeds the solubility in water by a factor of 51 (3.13/0.0608), while BAL's reported value exceeds the solubility in water by a factor of $158(9.60 / 0.0608)$. The values reported for Tank 38 are even greater with the Eurofins reported elemental mercury exceeding the solubility in water by a factor of 206 (12.5/0.0608), while BAL's reported value exceeds the solubility in water by a factor of $913(55.5 / 0.0608)$. 
An example of mercury speciation by IP-CV-ICP-MS is shown in Figure 3-2. As noted by BAL, ethyland phenylmercury are qualitative because these species are not fully oxidized and converted to inorganic mercury in the flow injection system. The detection limits on methylmercury are higher by this method than by CV-AFS.

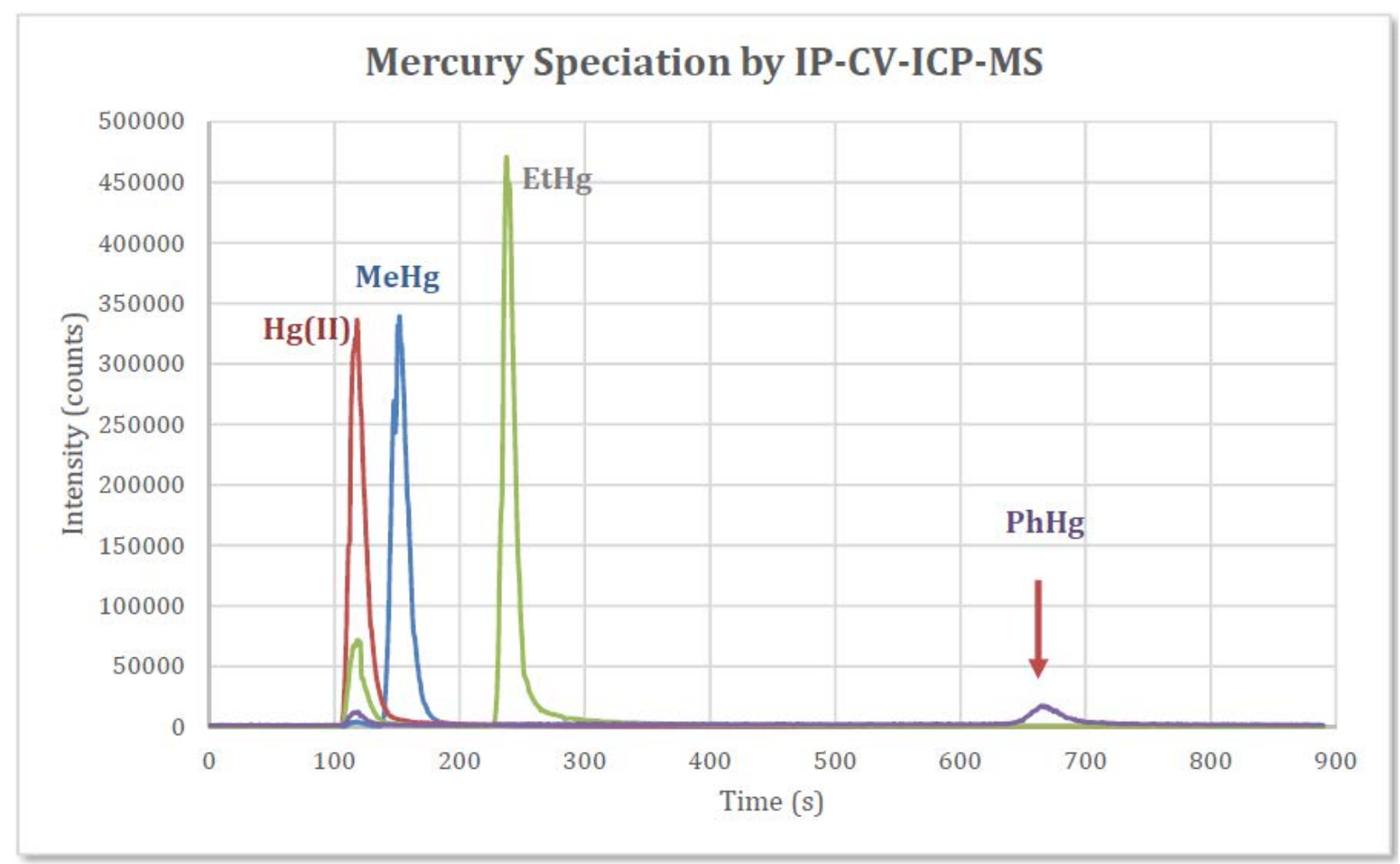

Figure 3-2 Example of mercury speciation by the BAL IP-CV-ICP-MS method. Peak labeled as $\mathrm{Hg}(\mathrm{II})$ is actually attributable to both $\mathrm{Hg}(\mathrm{I})$ and $\mathrm{Hg}(\mathrm{II})$ species. $^{27}$

\subsection{Laboratory Measurement Differences}

While BAL attempted a number of experimental methods in their analyses of the two SRS Tank samples, the final results the laboratory reported were based on CV-AFS measurements following established EPA methods, where available (specified in Table 3-1 and Table 3-2), except for their measurement of inorganic mercury, which was done by IP-CV-ICP-MS. The ion pairing method resulted in higher detection limits for most species over those that could be attained with CV-AFS. Therefore, for all species, other than inorganic mercury, the CV-AFS results were reported. Neither BAL nor Eurofins specified an EPA reference procedure for the determination of dimethylmercury. For the two species where the laboratories differed in their reported results, elemental and inorganic mercury, both laboratories followed their versions of EPA Method 1631 for elemental mercury and Eurofins also used this method for inorganic mercury.

BAL originally referred to their elemental method as total volatile mercury, but subsequent discussions between SRNL and BAL indicates this was based upon their belief that dimethylmercury may also amalgamate on the gold traps, along with the elemental mercury. They no longer believe this is the case, 
so the BAL 'total volatile' mercury measurement, as discussed in Section 3.2, is really elemental mercury. For Eurofins, 'total volatile' mercury is done by purging a solution onto an activated carbon trap.

Other than consideration of BAL's improved sum of species results, there is too little comparative data from SRS Tank samples analyzed by both laboratories to dictate which elemental and inorganic mercury values are "more" correct. Both laboratories followed their respective quality control procedures. In the case of elemental mercury, this is volatile species, highly susceptible to loss from solution, so it is more prone to under-reporting than over-reporting.

\subsection{Conclusions}

The analyses conducted by BAL on the Tank 22 and 38 samples and their agreement with those obtained from Eurofins FGS for total mercury, dissolved mercury, methylmercury, ethylmercury, and dimethylmercury provide a strong degree of confidence in these species measurements for samples submitted since March 2015 to Eurofins FGS. The present Eurofins FGS analyses did employ the improved techniques for SRS samples that they implemented over time after working with our materials. This included purging elemental mercury from the sample measured for inorganic mercury and utilizing separate replicates for elemental and dimethylmercury determinations. As a result the sum of species fractions was improved over their earlier measurements.

BrooksApplied Laboratories use of IP-CV-ICP-MS to determine inorganic mercury led to a significantly greater inorganic mercury fraction for both Tank 22 (21\% increase) and Tank 38 (40\% increase) over those values determined by Eurofins FGS. Staff at BAL also reported significantly more elemental Hg in both Tank 22 (3x) and Tank 38 (>4x) than reported by Eurofins FGS. Combining these two factors improved their sum of species fractions to $105 \%$ and $92 \%$ for Tank 22 and 38, respectively. Other than its contribution of an inorganic mercury value, the IP-CV-ICP-MS method did not have detection limits sensitive enough for the other mercury species to exceed those determinations by CV-AFS methods.

\subsection{Recommendations and Future Work}

This work leads to one recommendation for Eurofins FGS, that they attempt to close the mass balance on their analyses prior to reporting results on future SRS tank and process samples, with particular attention to elemental and inorganic mercury measurements. SRR should evaluate their elemental Hg limits for tanks and process vessels in light of the BAL data since the results reported are considerably higher than those reported by Eurofins.

The second recommendation involves future work by BAL on Tank 39 samples. Originally, there was no expectation for organomercury in this canyon waste receipt tank, but previous Eurofins FGS results ${ }^{19}$ indicated between 6-9\% of the total mercury was methylmercury. However, the sum of species fractions was very low, between $47-51 \%$ for the surface and depth samples. Questions that could be addressed by BAL include, "Are there other organomercury species present in this tank and/or would a reanalysis of this tank lead to a better overall mass balance and improved understanding of the chemistry that may be contributing to organomercury species formation?” 


\subsection{References}

1. Sudduth, C. B., Mercury Speciation, X-TTR-G-00002, Savannah River Remediation, Aiken, SC 29808 (May 2015).

2. Crawford, C. L., Bannochie, C. J., Task Technical and Quality Assurance Plan for Mercury Speciation Analyses in Savannah River Site Liquid Waste Systems, SRNL-RP-2015-00320, Rev. 0, Savannah River National Laboratory, Aiken SC 29808 (May 2015).

3. Bannochie, C. J., Results of Preliminary Hg Speciation Testing on 4Q14 Tank 50, 1 Q15 Tank 50, and SRNL 14-Day TCLP Leachate, SRNL-L3100-2015-00054, Rev. 1, Savannah River National Laboratory, Aiken, SC 29808 (June 2016).

4. Bannochie, C. J., Results of Hg Speciation Testing on Tank 21 and Solvent Hold Tank (SHT) Material, SRNL-L3100-2015-00068, Rev. 1, Savannah River National Laboratory, Aiken, SC 29808 (September 2015).

5. Bannochie, C. J., Results of Preliminary Hg Speciation Testing on Tank 22 and Waste Concentrate Hold Tank (WCHT) Material, SRNL-L3100-2015-00079, Rev. 1, Savannah River National Laboratory, Aiken, SC 29808 (May 2015).

6. Bannochie, C. J., Results of $\mathrm{Hg}$ Speciation Testing on 2Q14 Tank 50 WAC and CsDecontaminated Tank 21 Waste Samples, SRNL-L3100-2015-00084, Rev. 1, Savannah River National Laboratory, Aiken, SC 29808 (September 2015).

7. Bannochie, C. J., Results of Hg Speciation Testing on DWPF Batch 735 RCT and OGCT Samples, SRNL-L3100-2015-00105, Rev. 1, Savannah River National Laboratory, Aiken, SC 29808 (July 2016).

8. Bannochie, C. J., Results of Hg Speciation Testing on 2Q15 Tank 50 and Tank 21 TCLP Extraction Fluid Samples and Tank 49 Material, SRNL-L3100-2015-00106, Rev. 1, Savannah River National Laboratory, Aiken, SC 29808 (July 2016).

9. Bannochie, C. J., Results of Hg Speciation Testing on Tank 38 and $2 \mathrm{H}$ Evaporator Overhead Tank (OHT-1) Materials, SRNL-L3100-2015-00113, Rev. 0, Savannah River National Laboratory, Aiken, SC 29808 (June 2015).

10. Bannochie, C. J., Results of Hg Speciation Testing on Tank 43 and $2 \mathrm{H}$ Evaporator Overhead Tank (OHT-2) Materials, SRNL-L3100-2015-00115, Rev. 0, Savannah River National Laboratory, Aiken, SC 29808 (June 2015).

11. Bannochie, C. J., Results of Hg Speciation Testing on 3Q15 Tank 50, Salt Solution Feed Tank (SSFT), and Solvent Hold Tank (SHT) Materials, SRNL-L3100-2015-00144, Rev. 1, Savannah River National Laboratory, Aiken, SC 29808 (July 2016).

12. Bannochie, C. J., Results of Hg Speciation Testing on MCU Strip Effluent Hold Tank (SEHT) and Decontaminated Salt Solution Hold Tank (DSSHT) Materials, SRNL-L3100-2015-00150, Rev. 1, Savannah River National Laboratory, Aiken, SC 29808 (July 2016). 
13. Bannochie, C. J., Results of Hg Speciation Testing on Tanks 30, 32, and 37 Surface Samples, SRNL-L3100-2015-00202, Rev. 1, SRNL-L3100-2015-00202, Rev. 1, Savannah River National Laboratory, Aiken, SC 29808 (July 2016).

14. Bannochie, C. J., Results of Hg Speciation Testing on Tanks 30, 32, and 37 Depth Samples, SRNL-L3100-2015-00206, Rev. 1, Savannah River National Laboratory, Aiken, SC 29808 (July 2016).

15. Bannochie, C. J., Results of Hg Speciation Testing on DWPF SMECT-1, SMECT-3, and SMECT5 Samples, SRNL-L3100-2015-00218, Rev. 1, Savannah River National Laboratory, Aiken, SC 29808 (February 2016).

16. Bannochie, C. J., Results of Hg Speciation Testing on 4Q15 Tank 50, DWPF SMECT-2, and RCT-1 Samples, SRNL-L3100-2015-00219, Rev. 1, Savannah River National Laboratory, Aiken, SC 29808 (July 2016).

17. Bannochie, C. J., Results of Hg Speciation Testing on DWPF SMECT-4, SMECT-6, and RCT-2 Samples, SRNL-L3100-2016-00016, Rev. 0, Savannah River National Laboratory, Aiken, SC 29808 (February 2016).

18. Bannochie, C. J., Results of Hg Speciation Testing on DWPF SMECT-8, OGCT-1, and OGCT-2 Samples, SRNL-L3100-2016-00018, Rev. 0, Savannah River National Laboratory, Aiken, SC 29808 (February 2016).

19. Bannochie, C. J., Results of Hg Speciation Testing on Tank 39 and 1Q16 Tank 50 Samples, SRNL-L3100-2016-00021, Rev. 1, Savannah River National Laboratory, Aiken, SC 29808 (July 2016).

20. Bannochie, C. J., Results of Hg Speciation Testing on 3H Evaporator Overhead Samples, SRNLL3100-2016-00059, Rev. 0, Savannah River National Laboratory, Aiken, SC 29808 (March 2016).

21. Bannochie, C. J., Results of Hg Speciation Testing on Tank 21 (Salt Batch 9) and 2 Q16 Tank 50 WAC Samples, SRNL-L3100-2016-00105, Rev. 0, Savannah River National Laboratory, Aiken, SC 29808 (June 2016).

22. Bannochie, C. J., Results of Hg Speciation Testing on a Tank 41 Sample, SRNL-L3100-201600129, Rev. 0, Savannah River National Laboratory, Aiken, SC 29808 (July 2016).

23. Bannochie, C. J., "BrooksApplied (Part 1) - Eurofins Round Robin Samples (Part 22)”, Experiment L2320-00194-15, SRNL E-Notebook (Production), Savannah River National Laboratory, Aiken, SC 29808 (March 2016).

24. Crawford, C. L., Results for the Third Quarter Calendar Year 2016 Tank 50H Salt Solution Sample, SRNL-L3100-2016-00173, Rev. 0, Savannah River National Laboratory, Aiken, SC 29808 (October 2016).

25. Bannochie, C. J., Fellinger, T. L., Garcia-Strickland, P., Shah, H. B., Jain, V., and Wilmarth, W. R., Mercury in Aqueous Tank Waste at the Savannah River Site: Facts, Forms, and Impacts, SRNL-STI-2016-00630, Savannah River National Laboratory, Aiken, SC 29808 (October 2016). 
26. Telliard, W. A. Methyl Mercury in Water by Distillation, Aqueous Ethylation, Purge and Trap, and Cold Vapor Atomic Fluorescence Spectrometry; Method 1630; U.S. Environmental Protection Agency, National Service Center for Environmental Publications, U.S. Government Printing Office: Washington, DC, 1998.

27. $\quad$ Briscoe, M. L.; Gurleyuk, H. BrooksApplied Labs Project SRN-AK1601, P. O. Number 248248; Technical Report for Savannah River National Laboratory: Aiken, SC, August 28, 2016.

28. Clever, H. L; Johnson, S. A.; Derrick, M. E. "The Solubility of Mercury and Some Sparingly Soluble Mercury Salts in Water and Aqueous Electrolyte Solutions”. J. Phys. Chem. Ref. Data, 1985, 14 (3), 631-680. 


\section{Distribution:}

T. B. Brown, 773-A

M. E. Cercy, 773-42A

D. A. Crowley, 773-43A

D. E. Dooley, 773-A

A. P. Fellinger. 773-42A

S. D. Fink, 773-A

C. C. Herman, 773-A

D. T. Hobbs, 773-A

E. N. Hoffman, 999-W

J. E. Hyatt, 773-A

K. M. Kostelnik, 773-42A

B. B. Looney, 773-42A

T. O. Oliver, 773-42A

F. M. Pennebaker, 773-42A

G. N. Smoland, 773-42A

B. J. Wiedenman, 773-42A

W. R. Wilmarth, 773-42A

C. J. Bannochie, 773-42A

C. L. Crawford, 773-42A

S. H. Reboul, 773-42A

Records Administration (EDWS)

P. R. Jackson, DOE-SR, 703-46A

J. A. Crenshaw, 703-46A

H. P. Boyd, 704-27S

J. M. Bricker, 704-S

J. S. Contardi, 704-56H

T. L. Fellinger, 766-H

E. J. Freed, 704-S

J. M. Gillam, 766-H

B. A. Hamm, 766-H

E. W. Holtzscheiter, 766-H

J. F. Iaukea, 704-27S

V. Jain, 766-H

E. J. Kahal, 704-29S

C. J. Martino, 999-W

J. W. Ray, 704-27S

P. J. Ryan, 704-26S

M. A. Rios-Armstrong, 766-H

H. B. Shah, 766-H

D. C. Sherburne, 249-8H

C. Sudduth, 707-7E

R. E. Edwards, Jr., 766-H

R. T. McNew, 766-H

A. W. Wiggins, $241-168 \mathrm{H}$ 